\title{
ANALISIS SEMIOTIKA MODEL ROLAND BARTHES PADA MAKNA LAGU "REMBULAN" KARYA IPHA HADI SASONO
}

\author{
${ }^{1}$ Henny Sri Kusumawati, ${ }^{2}$ Nuryani Tri rahayu, ${ }^{3}$ Dwi Fitriana \\ ${ }^{1,2,3}$ Program Studi Ilmu Komunikasi FISIP \\ Universitas VeteranBangunNusantara Sukoharjo \\ Author Correspondence henny.sk83@gmail.com
}

\begin{abstract}
ABSTRAK
Musik disebut sebagai bahasa dari perasaan-perasaan yang dirasakan manusia (the language of emotions). Musik dan bahasa memiliki tujuan yang serupa yaitu mengomunikasikan sesuatu arti tertentu yang ingin disampaikan. Sebagaimana yang ingin dikomunikasikan Ipa Hadi Sasonodalam karya lagunya berjudul "Rembulan". Selain itu penelitian ini juga mendeskripsikan tentang persepsi masyarakat usia 21-24 di kalangan karang taruna Desa Gentan, Kecamatan Bulu, Kabupaten Sukoharjo terhadap lagu. Subyek penelitian adalah lagu "Rembulan" Karya Ipa Hadi Sasono. Metode yang digunakan dalam penelitian ini menggunakan Metode Semiotika Roland Barthes. Sumber data yang digunakan adalah sumber data primer dan sekunder. Teknik Keabsahan data menggunakan Triangulasi sumber. Teknik Pengumpulan data menggunakan content analysis dan wawancara. Berdasarkan hasil penelitian, dapat disimpulkan bahwa lagu "Rembulan" menggunakan dua macam simbol, yakni simbol verbal berupa syair atau lirik lagu yang mengandung makna tentang percintaan. Sedangkan simbol non verbal berupa unsur-unsur lagu yang indah dan lembut membuat lagu saling berkesinambungan. Persepsi yang didapat dari lagu "Rembulan" adalah persepsi positif karena bisa mendorong anak muda untuk membuat karya dan menjadi anak muda yang kreatif.
\end{abstract}

Kata kunci : lagu Rembulan Analisis Semiotik, Simbol Verbal, Simbol Non Verbal

\section{PENDAHULUAN}

Kehidupan manusia dan musik memiliki kaitan sangat erat, meski banyak yang tidak menyadarimya. Musik sering disebut sebagai bahasa dari perasaanperasaan yang dirasakan manusia (the language of emotions), sebutan ini bukan sesuatu yang tanpa alasan. Jika dilihat dari tujuannya, musik dan bahasa memiliki tujuan yang serupa yaitu mengomunikasikan sesuatu arti tertentu yang ingin disampaikan. Seperti yang diungkapkan Joseph Machlis, seorang profesor di bidang musik Queens College Newyork, ..."for music,like language, aims to communicate meaning. Like language too it possesses a grammar, a syntax, and a rhetoric. But is a different kimd of llanguage. (...dalam musik, seperti halnya bahasa, bertujuan untuk mengkomunikasikan makna. Seperti bahasa juga, musik memiliki tata bahasa, sintaksis, dan retorika. Tapi musik merupakan bentuk bahasa yang berbeda.)". Perkembangan musik sendiri telah dimulai sejak jaman pra-sejarah, seperti yang terekam dalam artefak daerah Timur Tengah dan Mesir Kuno tepatnya di daerah Mesopotamia, di sekitar sungai Tigris dan Euphrate yang merupakan tempat tinggal suku bangsa Sumeria, Babylonia dan Assyria. Artefak yang ditemukan bergambar instrumen musik yang sudah lengkap untuk memainkan himne pada tahun 800 SM. (Muttaqin \& Kustap, 2008 hal 93-95). 
Pada lagu, musik terkait pada bahasa. Artinya terkait pada bahasa karena isi dan bentuk dan teristimewa oleh hubungan bunyi dan kata-kata. Bahasa merupakan hal yang penting yang perlu dipelajari karena bahasa mempunyai fungsi dan peranan penting ketika berkomunikasi. Fungsi bahasa yang utama yaitu sebagai alat komunikasi yang digunakan setiap manusia. Seseorang dapat menggunakan ide, keinginan, pikiran dan menyampaikan informasi melalui bahasa sehingga bahasa merupakan sarana komunikasi yang sangat penting bagi manusia. Menurut (Suryono, Astuti, Rahayu, Hariyanto, \& Widayati, 2019), bahasa sebagai alat komunikasi yang sering digunakan untuk mengkritisi penguasa, menggambarkan keresahan masyarakat terhadap permasalahan sosial, politik, hukum dan ekonomi yang berkaitan dengan kesenjangan ekonomi, kemiskinan, korupsi, pengangguran, pemerintahan tangan besi, selain juga memiliki fungsi menghibur.

Dari uraian diatas jelas bahwa fungsi utama dari bahasa adalah sebagai alat untuk berkomunikasi bagi masyarakat penuturnya.

Dengan lirik lagu, seorang pencipta lagu dapat berkomunikasi dengan para pendengarnya. Karena melalui lirik lagu, pencipta lagu ingin menyampaikan pesan yang merupakan pengekspresian dirinya terhadap fenomena-fenomena yang terjadi di dunia sekitar, dimana dia berinteraksi di dalamnya. Dalam penciptaannya, para penulis lagu menggunakan kreativitas berbahasanya dalam mengambil diksi dan memadukan fenomena dalam masyarakat maupun alam sekitarnya. Budaya masyarakat yang terjadi di sekitar penulis lagu menjadi fenomena penciptaan lirik lagu, tak terkecuali masyarakat urban. Budaya urban yang ekspresif (Kusumaningsih, Darmini, Suparmin, \& Nugrahani, 2019). Lirik lagu dalam musik yang sebagaimana bahasa dapat menjadi sarana atau media komunikasi untuk mencerminkan realita sosial yang beredar dalam masyarakat. Lirik lagu dapat pula sebagai sarana untuk sosoalisasi dan pelestarian terhadap suatu sikap atau nilai. Oleh karena itu, ketika sebuah lirik lagu diaransir dan didengarkan kepada khalayak juga mempunyai tanggung jawab yang besar atas tersebar luasnya sebuah keyakianan, nilai-nilai, bahkan prasangka tertentu (Setianingsih, 2007:7).

Lirik lagu mempunyai kesamaan dengan puisi, bahwa puisi memiliki unusur-unsur berupa emosi, imajinasi ,pemikiran, ide, nada, irama, kesan panca indra, kata-kata kiasan, kepadatan dan perasaan yang tercampur-campur. Hal tersebut diungkapkan dalam media sama halnya dengan lirik lagu. Lirik lagu merupakan ekspresi berbahasa yang tak bisa menghindar dari kreativitas social berbahasa para penuturnya (Kusumaningsih, 2018; Kusumaningsih, Santosa, \& Subroto, 2018) sama halnya dengan penciptaan puisi. Dalam mengapresiasi puisi juga sering kali ditemukan pembacaan puisi yang disajikan secara musikal atau biasa disebut musikalisasi puisi. Lirik lagu biasanya dikemas dengan ringan dan mudah diingat. Setiap lagu memiliki cerita tersendiri sehingga lagu yang dinyanyikan bisa bernuansa sedih, senang, mayoun jenaka. Cerita tersebut merupakan pesan yang akan disampaikan kepada orang lain. Oleh sebab itu, banyak orang yang menggunakan lagu sebagai media mengungkapkan perasaan terhadap orang lain. Dalam lagu Rembulan karya Ipa Hadi Sasono ini menggunakan lirik lagu yang unik dan berbeda karena liriknya menggunakan bahasa Jawa seperti geguritan. 
Menurut Mariah Gipty, Lagu Rembulan pernah hits dikalangan pecinta musik campursari. Lagu ciptaan Ipa Hadi Sasono ini, mengisahkan seorang yang tidak dapat melupakan sang kekasih yang dianggap seperti rembulan.Sang kekasih yang sangat cantik yang selalu bersanding di batinnya. Dalam bahasa Indonesia, rembulan berarti Bulan.

Setiap lagu memiliki makna tersendiri bagi pendengarnya, dalam pemakaian sehari-hari makna digunakan dalam berbagai bidang maupun konteks pembicaraan. Lagu Rembulan memiliki makna percintaan dua sejoli yang menjalin kasih yang tiada henti. Kisah percintaan yang diwujudkan dalam lagu tidak pernah usang. Makna adalah bagian yang tidak terpisahkan dari semantik dan selalu melekat dari apa saja yang dituturkan, Pengertian dari makna sangatlah beragam. Para ahli mengakui, istilah makna (meaning) memang merupakan kata dan istilah yang membingungkan (Sobur, 2009:255). Orangorang sering menggunakan istilah pesan dan makna secara bergantian. Dapat dikatakan pesan itu tidak sama dengan makna, pesan bisa memiliki lebih dari satu makna, dan beberapa pesan bisa memiliki satu makna. Dalam hal ini, Ferdinand de Saussure mengungkapkan pengertian makna sebagai pengertian atau konsep yang dimiliki atau terdapat pada suatu tanda linguistik.

Analisis semiotika secara sederhana dapat digambarkan untuk mengetahui makna pada lirik lagu Rembulan karya Ipa Hadi Sasono. Secara semiotika pesan adalah penanda dan maknanya adalah petanda. Pesan adalah sesuatu yang dikirimkan secara fisik dari satu sumber ke penerimanya. Sedangkan makna dari pesan yang dikirimkan hanya bisa ditentukan dalam kerangka-kerangka makna lainnya (Danesi, 2010:22). Pemikiran Barthes ini mencakup konotasi dan denotasi. Barthes juga melihat aspek lain dari penanda yaitu mitos. Menurut Barthes mitos berada pada tingkat kedua penanda, tanda tersebut akan menjadi penanda baru yang kemudian memiliki penanda kedua dan membentuk makna baru.

Langer memandang makna sebagai sebuah hubungan kompleks diantara simbol, objek, dan manusia yang melibatkan denotasi (makna bersama) dan konotasi (makna pribadi) (Littlejohn, 2011:155).Dalam penjelasan Umberto Eco, makna dari sebuah wahana tanda (sign-vechicle) adalah suatu cultural yang dipergakan oleh wahana-wahana tanda yang lainnya, dengan begitu secara sistemantik menunjukkan pula tidaktergantungnya pada wahana tanda yang sebelumnya (Sobur, 2004:255).

\{Bibliography\}Dalam kaitan ini Kempson dalam Sobur (2004:256) berpendapat untuk menjelaskan istilah makna harus dilihat dari segi (1) kata, (2) kalimat, dan (3) apa yang dibituhkan pembicara untuk berkomunikasi. Broadback dalam Sobur (2004:262) menyajikan teori makna dengan cara yang cukup sederhana . ia menjernihkan pembicaraan awal makna dengan membagi makna tersebut kepada triga corak (Littlejohn, 2011:262).

a. Makna pertama inferensial, yakni makna satu kata (lambang) yang merupakan objek, pikiran, gagasan, konsep yang dirujuk oleh kata tersebut. Dalam uraian Odgen dan Richard, proses pemberian makna (reference process) ketika kita menghubungkan lambang dengan yang ditunjukan lambang (disebut rujukan atau referen). Suatu lambang dapat menunjukkan banyak rujukan. Atau satu rujukan diwakili oleh berbagai lambang. 
b. Makna kedua significance yang menunjukkan arti, suatu istilah yang dihubungkan dengan konsep-konsep lain. Fisher, memberikan contoh dengan kata phlogision. Kata ini dahulu dipakai untuk menjelaskan proses pembakaran. Benda menyala karena ada phlogision. Kini, setelah ditemukan oksigen, phlogision tidak berarti lagi.

c. Makna yang ketiga intensional, adalah makna yang dimaksud oleh seorang pemakai lambang. Harimurti Kridalaksana menyebutnya sebagai makna yang menekankan maksud pembicara (misalnya saya minta roti: saya akan memberi roti). Makna ini tidak terdapat dalam fikiran orang, hanya dimiliki dirinya saja. Dua makna intensional boleh jadi serupa tetapi tidak sama.

Penyampaian pesan dalam lagu mengandung simbol-simbol verbal maupun non verbal. Simbol non verbal yang digunakan adalah unsur-unsur lagu seperti tempo, melodi, dan tanda dinamik. Di samping itu simbol verbal yang digunakan meliputi tulisan atau lirik lagu. Penyampaian pesan lagu yang disampaikan dalam sebuah lagu menjadi hal yang penting karena menjadi ide cerita penulis lagu, lagu yang menggambarkan tentang seorang wanita yang sangat cantik yang memikat hati seorang pria. Namun yang menjadi permasalahan apakah ide cerita dalam lagu yang dimasukkan oleh penulis lagu dengan penikmat lagu berbeda sehingga bisa menimbulkan persepsi yang tidak tepat dengan penikmat lagu.

\subsection{METODE}

Metode yang digunakan dalam penelitian ini adalah metode penelitian kualitatif, "metode penelitian kualitatif adalah metode penelitian yang digunakan untuk meneliti pada kondisi objek yang alamiah (sebagai lawannya adalah eksperimen) dimana peneliti adalah sebagai instrumen kunci, teknik pengumpulan data dilakukan secara trianggulasi (gabungan), analisis bersifat induktif, dan hasil penelitian kualitatif lebih menekankan makna daripada generalisasi" (Sugiono, 2013:1). Strategi yang digunakan untuk mengetahui bagaimana makna tanda yang disampaikan dalam lagu "Rembulan" karya Ipa Hadi Sasono. Adapun objek sasaran yang diteliti terarah pada satu karakteristik atau subjek yang telah ditetapkan sebelumnya yaitu makna tanda dalam lagu "Rembulan". Strategi yang digunakan untuk mengetahui bagaimana makna tanda yang disampaikan dalam lagu "Rembulan" karya Ipa Hadi Sasono. Adapun objek sasaran yang diteliti terarah pada satu karakteristik atau subjek yang telah ditetapkan sebelumnya yaitu makna tanda dalam lagu "Rembulan".

\section{HASIL dan PEMBAHASAN}

\section{1. . Hasil}

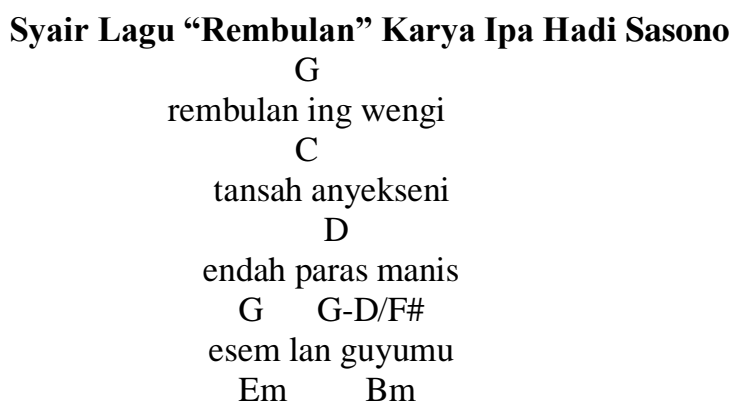




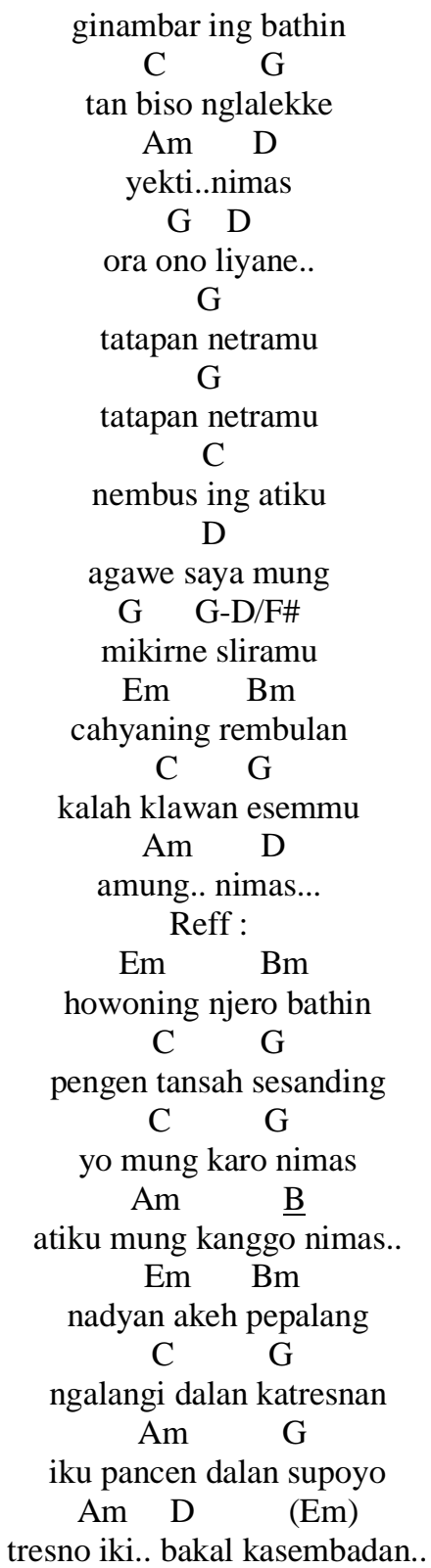

Pokok temuan yang ditemukan oleh peneliti berdasarkan hasil penelitian diantaranya dalam Lagu "Rembulan" Karya Ipa Hadi Sasono, antara lain:

1. Berdasarkan hasil penelitian yang dilakukan oleh penulis dapat diketahui dalam lagu "Rembulan" terdapat 12 simbol verbal dan 4 simbol non verbal.

2. Berdasarkan hasil penelitian yang dilakukan oleh penulis, dalam lagu "Rembulan" terdapat wujud simbol verbal dan non verbal, simbol verbal dalam lagu"Rembulan" berupa syair dan simbol non verbal berupa unsurunsur lagu.

3. Berdasarkan hasil penelitian yang dilakukan oleh penulis, dalam lagu "Rembulan", dapat diketahui Simbol verbal berupa syair mengandung makna denotatif yaitu Menceritakan kisah asmara, kisah asmara berawal dari pandangan pertama membuat jatuh hati melihat seorang wanita idaman yang disaksikan saat munculnya rembulan. 
Makna konotatif lagu ini berupa kalimat pujian dan mengandung makna konotatif sebagai janji.Mitos dalam lagu ini yaitu "Rembulan" adalah simbol kesempurnaan wanita.Sedangkan simbol non verbal berupa unsur-unsur lagu berupa tempo. Melodi, tanda dinamik, ide cerita.

4. Berdasarkan penelitian yang dilakukan penulis, persepsi anggota kalangan karang taruna laki-laki dengan perempuanyang menjadi sumber data beranggapan bahwa lagu ini dinilai cukup berhasil dalam menarik perhatian khalayak. Ini dibuktikan dengan hasil wawancara peneliti dengan bebearapa anggota karang taruna, persepsi anggota karang taruna cenderung sama dan positif, mereka beranggapan bahwa syair dalam lagu "Rembulan" mudah dimengerti dan memiliki makna positif bagi para kalangan remaja.

\section{HASIL DAN PEMBAHASAN \\ a. Makna yang terkandung dalam lagu "Rembulan" karya Ipa Hadi Sasono}

Lagu merupakan salah satu bagian penting sebagai sarana presentasi kepada pendengar, karena saling ikut dan terhanyut oleh sebuah lagu disebabkan liriknya sama atu hampir sama dengan keadaan saat itu atau sama dengan pengalaman yang pernah dialami. Alasan pendengar itu juga membuat banyak lagu bertemakan cinta yang memang ditujukan untuk remaja yang memang sedang memulai merasakan cinta pertama.

Salah satunya yakni lagu "Rembulan" karya Ipa Hadi Sasono. Lagu ini menggunakan daya tarik yang original untuk mempengaruhi khalayak yang mendengarkan. Pesan-pesan dalam lagu ini pun disampaikan dengan dilengkapi pengunaan simbol verbal dan non verbal. Dalam memaknai simbol yang digunakan, peneliti menganalisa secara rinci lirik demi lirik pada lagu "Rembulan" karya Ipa Hadi Sasono. Setiap simbol verbal memiliki tiga makna, ketiga makna tersebut meliputi makna denotatif, makna konotatif, dan makna mitos. Makna denotatif merupakan makna sebenarnya dari simbol tersebut. Makna konotatif merupakan makna kiasan, dimana simbol diasosiasikan dengan tanda lain. Makna mitos merupakan makna yang berkembang pada daerah tertentu, dimana sebuah simbol dalam suatu daerah dengan daerah lainnya belum tentu sama maknanya.

Simbol verbal berupa syair mengandung makna denotatif yaitu Menceritakan kisah asmara, kisah asmara berawal dari pandangan pertama membuat jatuh hati melihat seorang wanita idaman yang disaksikan saat munculnya rembulan. Lelaki menaruh hati saat melihat kecantikan seorang wanita tersebut dan memendam isi hati sudah lama dusembunyikan. Tatapan mata dari wanita tersebut selalu tergambar dihati tidak bisa dilupakan dan tidak ada yang lain yang bisa menggantikannya, seolah cahaya dari rembulan mengalahkan kecantikannya, senyumannya. Jika sekedar memandang lelaki mersa tidak puas jika tidak bersandinh dengan wanita idaman hati. Lelaki mengungkapkan perasaan di hati di saksikan saat munculnya saat munculnya sinar rembulan. Rembulan menghiasi malam menjadi saksi kisah asmara menambah mesra antara lelaki dan wanita idaman. Saat terjadi pertengkaran antara pasangan berbagai masalah datang menerpa kisah cinta asmara mereka, akan tetapi sang lelaki dan wanita berjanji selalu menjaga kelangenggan dan keutuhan asmara mereka. 
Rembulan dikonotasikan sebagai sosok yang hidup sosok yang bisa melihat, lagu ini juga mengandung makna konotatif sebagai kalimat pujian, pujian untuk seorang wanita yang dicintainya tidak ada yang lain selain dirinya.Makna yang ketiga yakni mengandung makna konotatif sebagi janji, janji seorang lelaki bahwa cintanya hanya untuk wanita tersebut tidak ada yang lain lagi.

Rembulan memiliki makna mitos yaitu sebagai simbol kesempurnaan wanita, Rembulan mempunyai makna kecantikan maupun kesempurnaan untuk seorang wanita, wanita yang mempunyai wajah cantik dan senyum yang indah seperti Rembulan di malam hari.

Proses komunikasi tidak terlepas dari simbol dan pesan. Herusartoto menyatakan simbol berasal dari kata "symbolos" yang berarti tanda atau ciri yang memberitahukan sesuatu kepada seseorang (Sobur, 2003:155). Dalam kamus besar Bahasa Indonesia, simbol berarti semacam tanda, lukisan, perkataan, lencana, dan sebagainya yang menyatakan suatu hal atau mengandung maksud tertentu. Menurut Peirce (dalam Derrida dalam Sobur, 2003:156) menyatakan bahwa simbol diartikan sebagai tanda yang mengacu pada objek tertentu diluar tanda itu sendiri. Hubungan antara simbol sebagai penanda dengan sesuatu yang ditandakan (petanda) bersifat konvensional. Berdasarkan konvensi itu pula masyarakat menafsirkan ciri hubungan antara simbol dengan objek yang dijadikan acuan untuk menafsirkan maknanya.

Lagu "Rembulan" mengandung empat simbol non verbal yaitu Tempo, melodi, tanda dinamik, dan ide cerita. Tanda tempo pada lagu ini tepat untuk lagu dengan tema cinta atau asmara dengan tempo lambat atau largissimo (68) dan tenang sesuai tema lagu (Yohanes, 6 September 2019)

Hal tersebut sesuai dengan teori menurut Mudjilah (2004:133), yang menjelaskan bahwa tanda tempo berfungsi untuk menunjukkan cepat lambatnya sebuah lagu yang dinyanyikan, secara garis besar tanda tempo dibagi menjadi tiga kelompok, yaitu tanda tempo cepat (allegro, allegreto allegresimo, presto), tanda tempo sedang (moderato, allegro moderato, andante), tanda tempo lambat (largo, largissimo, largeto, grave).

Melodi pada lagu 'Rembulan' terasa lebih indah dengan balutan harmoni diatonis minor dan kombinasi mayor dengan suasana mellow yang dipadu dengan bunyi-bunyian instrument gamelan. Ide cerita dalam lagu ini sangat bagus dan komersial karena bertemakan cinta dengan pesan moral yang baik, yaitu menceritakan tentang percintaan seorang laki-laki terhadap wanita yang dicintainnya yang takkan terpisahkan hingga kepelaminan walaupun banyak halangan dan rintangan menghadang akan tetapi tidak akan meruntukan kisah cinta mereka berdua (Sutarto, 6 September 2019)

Hal tersebut sama dengan teori Grimornia (2014:16) yang menjelaskan bahwa susunan rangkaian nada (bunyi dengan getaran teratur) yang terdengar berurutan serta berirama dan mengungkapkan suatu gagasan atau ide.

Tanda dinamik pada lagu "Rembulan" ini lembut(pianissimo) tapi agak kurang terasa karena menggunakan beat yang konstan hanya terasa sedikit perubahan dinamika pada bait dan refrain (Yohanes, 6 September 2019).

Hal tersebut sama dengan teori Mudjilah (2004:67) yang menjelaskan bahwa tanda tanda yang menyatakan tingkat atau volume suara atau keras lunaknya perubahan-perubahan, tanda dinamik terbagi menjadi dua golongan yaitu tanda dinamik lembut (piano,pianissimo, pianissimo, posibile, mezo piano, decresscendo) 
dan tanda dinamik keras (forte, fortessimo, fortessimo assaim, mezzo forte, cressendo)

Dari hasil penelitian, keseluruhan narasumber memiliki interpretasi yang sama terhadap simbol verbal tersebut, yaitu memiliki makna itu memang jalan supaya cinta mereka dapat terlaksana menjadi kenyataan dan berakhir bahagia, jalan yang harus ditempuh untuk mewujudkan cintanya pada orang yang dicintainya.

\section{b. Persepsi Masyarakat terhadap Lagu "Rembulan" karya Ipa Hadi Sasono}

Berdasarkan penelitian yang dilakukan penulis, keseluruhan narasumber yang menjadi sumber data beranggapan bahwa lagu ini dinilai cukup berhasil dalam menarik perhatian khalayak. Ini dibuktikan dengan hasil wawancara peneliti dengan beberapa anggota Karang Taruna sebagai berikut :

Syair atau lirik dalam lagu "Rembulan" mudah dimengerti karena liriknya mudah dipahami seperti bahasa sehari-hari. sebagian besar narasumber mengetahui lagu Rembulan untuk seorang wanita, karena di dalam lirik lagu dan sesuai judulnya jika Rembulan memang simbol untuk wanita serta bisa sesuai dengan perasaan hati sang pendengar.Lirik lagu Rembulan sesuai dengan Kesesuaian Budaya Jawa karena Liriknya menggunakan bahasa jawa yang selaras, indah seperti puisi, tara lirik lagu dan musiknya berkesinambungan serta mudah dimengerti. Hal ini terbukti dari banyaknya kalangan karang taruna laki-laki maupun perempuan di karang taruna yang mendengarkan lagu tersebut.

Hal tersebut sesuai dengan teori (Awe. 2003:51) yang menjelaskan bahwa lirik lagu merupakan ekspresi seseorang tentang suatu hal yang sudah dulihat didengar maupun dialaminya. Lirik atau syair lagu merupakan satu bagian penting sebagai sarana presentasi kepada pendengar karena saling ikut terhanyut oleh sebuah lagu disebabkan liriknya sama atau hampir sama dengan keaadaan saat itu atau sama dengan pengalaman yang dialami.

Musik dalam lagu "Rembulan" ini sangat indah karena dengan adanya komposisi musik yang sederhana penggabungan musik klasik serta gamelan menambah syahdu lagu Rembulan, tidak lupa dengan latar tempat juga sesuai karena didalam Video klip lagu Rembulan berada disebuah candi serta dilengkapi gamelan dan di lengkapi dengan pakaian adat jawa yang disebut lurik. Seluruh narasumber memiliki persepsi yang sama tentang musik dan latar dalam lagu ini.

Hal tersebut sesuai dengan teori (Banoe,2003:288) musik merupakan cabang seni yang membahas dan menetapkan berbagai suara kedalam pola-pola yang dapat dimengerti manusia. Gaya khas pakaian, tarian, bahasa dan hubungan gender merupakan bagian ciri-ciri budaya yang berkaitan dengan era rock and roll (Sobur, 2006:145).

Mereka beranggapan bahwa lagu Rembulan ini mempunyai makna tentang percintaan walaupun makna lagu ini tentang percintaan tetapi dalam lirik lagu ini menggunakan bahasa jawa yang sopan dan indah sehingga tidak menimbulkan kalimat atau bahasa yang sara. Sebagian besar narasumber memiliki kesan tersendiri untuk lagu ini karena lagu Rembulan ini menarik dan jika dihayati makna lagu tersebut bisa sampai ke hati pendengar yaitu seorang laki-laki yang memperjuangkan cintanya untuk wanita yang dicintainya.

Hal tersebut sama dengan teori Louis Hjemlslv (2011) yang menjelaskan bahwa bahasa mempunyai bentuk dan substansi. Substansi adalah kata atau ungkapannya, sedangkan bentuk adalah apa yang diberi oleh pembicara kepada kata 
yang dipakainya. Melalui bentuk yang dipilih oleh pembicara maka suatu kata memperoleh arti dan makna.

Persepsi dari anggota karang Taruna yang berpendidikan dari SMA atau SMK sampai yang mengenyam pendidikan diploma maupun sarjana, mereka mempunyai interpretasi yang sama yang menyatakan bahwa lagu Rembulan ini mempunyai persepsi dan makna yang positif karena perlu sekali anak muda mengapresiasikan karyanya dengan cara membuat lagu seperti dalam lagu Rembulan tersebut menjadi anak muda yang kreatif, tidak hanya sekadar cintacintaan saja.

Hal tersebut sesuai dengan teori Miftah Toha (2003:145) yang menyatakan bahwa interpretasi merupakan suatu aspek kognitif dari persepsi yang sangat penting yaitu proses memberikan arti kepada stimulus yang diterimanya. Proses interpretasi tersebut bergantung pada cara pendalaman, motivasi, dan kepribadian seseorang. Faktor dominan yang memberi pengaruh pada persepsi lagu "Rembulan" dipengaruhi dari faktor pengalaman masa lampau, seperti ide cerita pada lagu "Rembulan" yang bisa diterima langsung ke hati pendengar.

Berdasarkan hasil penelitian yang dilakukan oleh peneliti, keseluruhan narasumber beranggapan sama bahwa lagu "Rembulan" mempunyai ide cerita yang bagus yaitu makna tentang percintaan, lagu "Rembulan" menceritakan tentang seorang lelaki yang sangat mecintai wanita yang kecantikannya mengalahkan rembulan hingga apapun diberikan hanya untuknya dan semuanya untuk dia walupun banyak halangan dan rintangan menghadang tidak meruntuhkan mahligai cinta mereka berdua takkan dan terpisahkan hingga kepelaminan.

Hal tersebut sesuai dengan teori Kamus Besar Bahasa Indonesia yang menyatakan bahwa ide lagu merupakan suatu gagasan pokok atau ide pikiran tentang suatu hal, salah satunya dalam membuat suatu tulisan, dan merupakan inti persoalan yang dikemukakan penyair dalam sebuah karya sastra.

\section{SIMPULAN}

Melalui analisis yang telah dilakukan peneliti pada bab sebelumnya mengenai Analisis Semiotik Makna Lagu "Rembulan" karya Ipa Hadi Sasono. Berdasarkan penelitian yang telah dilakukan, penulis menarik kesimpulan sebagai berikut:

1. Makna yang terkandung dalam lagu "Rembulan" karya Ipa Hadi Sasono yaitu makna denotatif, makna konotatif dan mitos.

a. Makna denotatif dari keseluruhan lagu "Rembulan" yaitu menceritakan tentang kisah asmara seorang lelaki dan perempuan yang disaksikan oleh rembulan dimalam hari, menceritakan tentang percintaan tak akan terpisahkan sampai kepelaminan walaupun banyak halangan dan rintangan menghadang.

b. Makna konotatif dari keseluruhan lagu "Rembulan" yaitu kalimat atau ucapan janji bahwa cintanya hanya untuk seorang wanita saja.

c. Mitos dari keseluruhan lagu "Rembulan" bahwa "Rembulan" merupakan simbol kesempurnaan maupun kecantikan wanita.

Lagu "Rembulan" karya Ipa Hadi Sasono mengandung Wujud simbol verbal dan verbal, simbol verbal berupa syair lagu sedangkan simbol non verbal berupa unsur-usnur lagu seperti:

d. Tempo pada lagu "Rembulan" menggunakan tempo yang lambat (largissimo) 
e. Melodi pada lagu "Rembulan" ini indah dengan suasana mellow yang dipadu dari alat musik instrument gamelan.

f. Tanda dinamik pada lagu "Rembulan" menggunakan tanda dinamik lembut (pianissimo)

g. Ide cerita dalam lagu "Rembulan' sangat bagus dan komersial kerena bertemakan cinta dengan pesan moral yang baik.

2. Persepsi yang terkandung dalam lagu "Rembulan" karya Ipa Hadi Sasono Berdasarkan keseluruhan lagu Berdasarkan hasil penelitian yang dilakukan prneliti, hampir seluruh masyarakat yang menjadi narasumber mempunyai persepsi yang sama yang menyatakan kesan dan tanggapan bahwa lagu "Rembulan" karya Ipa Hadi Sasono merupakan lagu yang mempunyai makna tentang percintaan, seorang laki-laki yang menyukai seorang wanita yang kecantikannya mengalahkan cahaya dari Rembulan, cinta yang takkan terpisahkan walaupun banyak rintangan dan halangan tidak akan meruntuhkan maligai cinta mereka. Lagu "Rembulan" karya Ipa Hadi Sasono merupakan lagu yang menarik perhatian dan mempunyai persepsi positif karena lagunya bisa mendorong anak muda menjadi kreatif dengan meghasilkan karya seperti melalui lagu.

\section{DAFTAR PUSTAKA}

Aufa Afifah, Hasna. 2017. Makna Lirik Lagu Tradisional Anak-Anak Amefuri (Kajian Semiotika). Jurnal Ayumi, Vol.4 No. 2, September 2017. Hlm 175-186. www.ejurnal.unitomo.ac.id diakses pada tanggal 10 April 2019 pukul 09.30 WIB.

Awe, Makoo. 2003. Nyanyian di Tengah Kegelapan. Jakarta: Kepustakaan Populer Gramedia

Banoe, P. (2003). Kamus Musik. Yogyakarta : Kanisius

Barthes, Roland. 2007. Membedah Mitos-Mitos Budaya Massa: Semiotik atau Sosiologi Tanda, Simbol dan Representasi. Yogyakarta: Jalasutra.

Danesi, Marcel. 2010. Pesan, Tanda, dan Makna. Yogyakarta: Jalasutra.

Effendy, Uchjana Onong. 2004. Ilmu Komunikasi Teori dan Praktek. Bandung: PT. Remaja Rosdakarya.

Eco, Umberto. 2009. Teori Semiotika. Bantul: Kreasi Wacana.

Fitri, Syarif. 2017. Analisa Semiotik Makna Motivasi Lirik Lagu Cerita Tentang Gunung dan Laut Karya Payung Teduh. Jurnal Komunikasi, Vol. VIII No. 3, September 2017. www.ejournal.bsi.ac.id diakses pada tanggal 9 April pukul 15.00 WIB.

Grimonia, Eya. 2014. Dunia Musik (Sains Musik Untuk Kebaikan Hidup). Bandung: Nuansa Cendekia. 
Herusartoto, Budiono. 2008. Simbolisme Jawa. Kanisius: Yogyakarta.

Hidayat, Rahmat. 2014. Analisis Semiotika Makna Motivasi Pada Lirik Lagu Laskar Pelangi Karya Nidji. Jurnal Ilmu Komunikasi, Vol.2 No. 1, 2014. Hlm 243-258. www.ejournal.ilkom.fisip.unmul.ac.id diakses pada tanggal 11 April 2019 pukul 02.35 WIB.

Hoed, H. Benny. 2011. Semiotik dan Dinamika Sosial Budaya. Beji Timur Depok. Cetakan Pertama.

Hovland, Carl L.2007. Definisi Komunikasi. PT. Raja Grafindo Persada: Jakarta.

H.B. Sutopo. 2002. Metode Kualitatif Dasar Teori dan Terapannya dalam penelitian. Surakarta: Sebelas Maret University Press.

Jamalaus. 1988. Panduan Pengajaran Buku Pengajaran Musik melalui Pengalaman Musik. Jakarta: Proyek Pengembangan Lembaga Pendidikan Tenaga Kependidikan.

Karomatunisa, Dina. 2017. Semiotika Korupsi dalam Lirik Lagu Rekening Gendut karya Iwan Fals. Jurnal Komunikasi, Vol. 9 No.. 2, 16 Oktober 2017. www.ejournal.uinjkt.ac.id diakses pada tanggal 26 September 2019 pukul 11.30 WIB.

Kurniawan. 2001. Semiologi Roland Barthes. Magelang. Yayasan Indonesiatera Anggota IKAPI.

Kusumaningsih, D. (2018). “ Kesaktianmu” an Expression of Language Beauty with the Content of Infidelity in a Popular Love Song Study of Language Creativity and Sexism, 231(Amca), 620-623.

Kusumaningsih, D., Darmini, W., Suparmin, S., \& Nugrahani, F. (2019). The Expressive Urban Cultures Exposed in Vulgar Song Lyrics ( The Study of Language Sexism ). https://doi.org/10.4108/eai.21-12-2018.2282661

Kusumaningsih, D., Santosa, R., \& Subroto, H. D. E. (2018). Vulgar and Obscene Terms in Indonesian Song Lyrics, 166(Prasasti), 60-65.

Suryono, J., Astuti, P. I., Rahayu, N. T., Hariyanto, H., \& Widayati, M. (2019).

Karikatur Iklan Politik Media Luar Ruang Jangan Membeli Kucing Dalam Karung.

Profetik: Jurnal Komunikasi, 12(1), 46. https://doi.org/10.14421/pjk.v12i1.1539

Kusumarini, Yusita. 2006. Analisis Teks dan Kode Interior Gereja Karya Tadao Ando.Jakarta : Petra Departmen.

Liliweri, Alo. 2011. Komunikasi: Serba Ada Serba Makna. Jakarta: Kencana Media Group. 
Littlejohn , Stephen W, Karen A. Foss. 2009. Teori Komunikasi. Jakarta: Salemba Humanika.

Lutfiani, Anis. 2018. Analisis Semiotika Model Roland Barthes pada Lagu Mars Perindo. Jurnal Ilmu Komunikasi, Vol.8 No. 3, 12 Februari 2018. www.ejournal.umpo.ac.id diakses pada tanggal 26 september 2019 pukul 10.00 WIB.

Masinambow , E. K. M, Hidayat Rahayu, S. 2001. Semiotik mengkaji tanda dalam artifak. Jakarta. Balai Pustaka.

Miftah, Thoha. 2003. Kepemimpinan dan Manajemen. Jakarta: PT. Raja Grafindo Persada.

Moleong, Lexy J. 2007. Metodologi Penelitian Kualitatif. Bandung: Rosdakarya.

Mudjilah, H.S.2004. Diktat Teori Musik Dasar. Yogyakarta: UNY.

Mulyana, Deddy. 2005. Ilmu Komunikasi Suatu Pengantar. Bandung: PT. Remaja Rosdakarya.

Nurdiansyah, C. 2018. Analisa Semiotik Makna Motivasi Berkarya Lirik Lagu Zona Nyaman Karya Fourtwenty. Jurnal Komunikasi, Vol. 9 No. 2, September 2018. Hlm 161-167. www.ejournal.bsi.ac.id diakses pada tanggal 10 April 2019 pukul 08.30 WIB.

Pratiwi, Ardhina. 2018. Representasi Citra Politik Hary Tanoesoedibjo Studi Semiotika Roland Barthes Dalam Video Mars Partai. Jurnal komunikasi, Vol.11 No. 2, Oktober 2018. www.ejournal.uin-suka.ac.id diakses pada tanggal 11 April 2019 pukul 03.00 WIB.

Putra Nugraha, Rahmadya. 2016. Konstruksi Nilai-Nilai Nasionalisme Dalam Lirik Lagu Analisis Semiotika Ferdinand De Saussure Pada Lirik Lagu Bendera. Jurnal Ilmu Ekonomi dan Sosial, Vol.5 No.3, November 2016. Hlm 290-303. www.ejurnal.mercubuana.ac.id diakses pada tanggal 11 April 2019 pukul 12.30 WIB.

Setianingsih, Ida. 2007. Penggambaran Perempuan dalam Lirik Lagu. Skripsi Surabaya: FIA Ilmu Komunikasi UPN Veteran.

Sobur, Alex. 2006. Semiotika Komunikasi . Bandung: PT. Rermaja Rosdakarya.

Sobur, Alex. 2009. Analisis teks media suatu analisis untuk wacana, analisissemiotika dan analisis framing. Bandung; PT. Remaja Rosdakarya.

Stoner, James A.F, 2010. Manajemen. Jakarta : Airlangga.

Sugihartono, dkk. 2007. Psikologi Pendidikan. Yogyakarta: UNY Press. 
Sugiyono. 2013. Metodelogi Penelitian Kuantitatif, Kualitatif dan R\&D. Bandung: Alfabeta.

Sujatmiko, Bagus. Ropingi El Ishaq. 2015. Pesan Dakwah Dalam Lagu Bila Tiba. Jurnal Komunikasi, Vol.9 No. 2, Juli- Desember 2018. www.ejurnal.iainpurwokerto.ac.id diakses pada tanggal 12 April 2019 pada pukul 08.45 WIB.

Suryono, J., Astuti, P. I., Rahayu, N. T., Hariyanto, H., \& Widayati, M. (2019).

Karikatur Iklan Politik Media Luar Ruang Jangan Membeli Kucing Dalam Karung.

Profetik: Jurnal Komunikasi, 12(1), 46. https://doi.org/10.14421/pjk.v12i1.1539

Syafiq Muhammad. 2003. Ensiklopedia Musik Klasik. Yogyakarta: Adicitia Karya Syarif, Ahmad.2013. Konstruksi Modernitas Dalam Album Radiohead Analisis Semiotika Pada Lirik Lagu dan Atwork Album Ok Computer. Jurnal Komunikasi. www.ejournal.unhas.ac.id diakses pada tanggal 26 September 2019 pukul 11.00 WIB.

Vardiansyah Dani. 2004. Pengantar Ilmu Komunikasi. Bogor: Ghalia Indonesia.

Vera, Nawiroh. 2014. Semiotika Dalam Riset Komunikasi. Bogor: Ghalia Indonesia.

Wali Al Khalidi Muhammad, Hamdani, M. Syam. 2017. Representasi Nilai-Nilai Moral Dalam Lirik Lagu Doda Idi Studi Semiotik Terhadap Lirik Lagu Doda Idi Dalam Album Nyawoung. JIM FISIP Unsyiah, Vol.3 No. 4, November 2017. Hlm 417-428. www.ejurnal.jim.unsyiah.ac.id diakses pada tanggal 13 April 2019 pukul 10.35 WIB.

Winduwati, Septia. 2017. Representasi Seks Bebas pada Lirik Lagu Dangdut Analisis Semiotika Saussure Pada Lirik Lagu Cinta Satu Malam. Jurnal Muara Ilmu Sosial, Humaniora, dan Seni Vol. 1, No. 2, Oktober 2017. Hlm. 346-349. FIKOM UNTAR. www.ejournal.untar.ac.id Diakses pada tanggal 9 April 2019 pukul 14.56 WIB.

Youtube : https://m.youtube.com/watch?v=71j2-HuurEY 